\title{
Agricultural productivity: closing the gap between Brazil and the United States
}

\section{José Eustáquio Ribeiro Vieira Filho and Armando Fornazier}

ABSTRACT
Since the 1970s, Brazilian agriculture has undergone far-reaching changes and has played a major role in agricultural production worldwide. This article assesses the structural heterogeneity prevailing in Brazilian and United States agriculture by studying total factor productivity (TFP), which has increased in both economies, mainly through technologies allowing for economies in the use of land and labour. Although higher growth rates have enabled Brazil to narrow the productivity gap with the United States, this does not mean its productivity is superior. Each country's production structure has specific features; and productivity differences can be seen not only between but also within countries, owing to a variety of factors, including climate, technology and learning in the production process. Resource use has become more efficient in both countries, enabling them to produce more with fewer inputs.
Q1, O3, Q55

José Eustáquio Ribeiro Vieira Filho is a planning and research technician in the Regional, Urban and Environmental Studies Department (DIRUR) of the Institute of Applied Economic Research (IPEA). jose. vieira@ipea.gov.br

Armando Fornazier teaches at the Faculty of Agronomy and Veterinary Medicine (FAv) of the University of Brasilia (UNB), Brazil. armandouenf@yahoo.com.br 


\section{I}

\section{Introduction}

In recent decades, Brazilian agriculture has undergone major transformations that have resulted in the sector's modernization, with the incorporation of technology and productivity growth. Brazil has become a major world producer of food and biofuels, alongside other countries such as the United States. Nonetheless, some farm units operate with little technology and low productivity levels, remaining a long way from modern development models. ${ }^{1}$ Some producers are often excluded from markets and sometimes exist in a situation of rural poverty, owing to their low level of production. This reflects the heterogeneous nature of Brazilian agriculture.

Labour productivity, calculated as the ratio between value added and the population employed on each farm, is the variable generally used to measure structural heterogeneity in studies by the Economic Commission for Latin America and the Caribbean (ECLAC) (Pinto, 1970; Nohlen and Sturm, 1982; Sunkel and Infante, 2009; ECLAC, 2010; Vieira Filho, Santos and Fornazier, 2013). Structural heterogeneity can be measured through differences in labour productivity, either between countries (referred to here as the international productivity gap), or between sectors (industry, services and agriculture) or within agriculture itself (comparing specific farmers and crops).

The comparison aims to display the external competitiveness models followed by Brazilian agriculture, based on narrowing the international productivity gap, and to demonstrate the dual form of development that persists in the economy and prevents segments ignored by the technological modernization process from gaining productive inclusion.

According to Fornazier and Vieira Filho (2012), Vieira Filho, Santos and Fornazier (2013), and Vieira Filho (2013), the productivity of farming activity varies greatly, particularly in Brazil. While some producers use modern techniques to increase productivity, others can only adopt less technology-intensive techniques owing

\footnotetext{
1 For an extended analysis of the results of the 2006 agricultural census, see Gasques and others (2010). The study provides a general overview of the most recent transformation in Brazilian agriculture. Buainain and others (2014) provides a wide-ranging discussion on technological transformations in Brazilian agriculture in 1960-2015, when Brazil shifted from being a net food importer to an exporter and a major global producer (as from the 1980s).
}

to difficulties in accessing more modern technologies, or even obstacles related to the adaptation process.

The process of combining factors of production expands as agriculture modernizes, since farmers have the chance to adopt technologies that enable them to economize on certain resources (such as land and labour) and replace them with others (such as a larger amount of capital). To modify the production process, agricultural policies themselves -including policies in relation to credit (which is often subsidized) - have increased the capitalization of agriculture by fostering relations with other sectors, such as input industries and agribusiness, commerce and supermarkets, among other segments linked to production; and by defining models and promoting credit.

Development does not occur homogeneously across countries and regions, or even within a given sector or activity. During the process, differences are created in the economic, social, political, technological and cultural environments. The theoretical discussion on developmental differences between countries began in ECLAC in the 1950s, when the dissimilarities between the developed centres and the developing peripheries were studied (Nohlen and Sturm, 1982).

Pinto (1970) had already defined structural heterogeneity as a visible phenomenon in developing countries, particularly in Latin America. It was claimed that the productivity of modern agriculture was as much as 14 times higher than that of the traditional sector. Not all producers have succeeded in modernizing; and there are significant regional differences which can explain the co-existence of modern and backward sectors.

Differences between sectors, or even within the same economic activity, reflect problems of access to financial resources for modernization, and a lack of stakeholder knowledge (social capital), which impair capacity to promote changes. Cultural, climatic and regional factors also can disrupt local production and increase disparities between regions.

Differences between and within sectors form part of Brazil's history. According to Fornazier and Vieira Filho (2012) and Vieira Filho (2013), heterogeneity can be seen both in production and across the region. The coexistence of a modern agricultural sector targeting the external market, with another that is almost exclusively devoted to the subsistence of rural families and supplying 
small local markets has a long history. Irrespective of size, the most productive agriculture is comparable with agriculture at the global technological frontier.

In the economic sphere, a number of indicators can be used to examine structural heterogeneity. For example, Nohlen and Sturm (1982) argue that productivity can be used as an indicator to define the scope of research and measurements in the economy. Creating indices makes it possible to identify the disparities that exist and the path of the development models of specific activities. According to ECLAC (2010, p. 24): "Achieving productive convergence requires closing productivity gaps with more competitive countries, while also reducing internal structural heterogeneity. These social and productivity gaps can literally be "mapped out," as they are reflected in —and partially caused by — territorial segmentation."

When comparing agricultural activity between countries, it is important to study the history of their development by analysing the factors that caused them to diverge through time. Disparities with respect to more modern sectors or countries decrease or increase over the years, as factor combinations improve in the more advanced sectors or countries, where there is a high level of accumulated knowledge. It is therefore important to evaluate productivity to determine technological and productive differences.
The aim of this study is to judge whether the development of the Brazilian economy is approaching the productivity gains achieved at the technological frontier of agricultural production, and to analyse the structural heterogeneity present in that sector. The Brazilian agricultural sector is compared with its counterpart in the United States, which in this study is taken as a benchmark representing the technological frontier. The study analyses how the productivity gaps between Brazil and the United States have behaved through time, specifically in terms of differences in total factor productivity (TFP); and a framework is provided to compare the two countries.

The results show that, although agricultural productivity in Brazil has converged with that of the United States over the last four decades, there is still considerable productive heterogeneity in Brazilian agriculture. While TFP is converging in the two countries, there is still a very high level of intra-regional heterogeneity in Brazil's farming sector.

This article is organized as follows: section II discusses agricultural development in both countries and section III presents the method of analysis, which consists of measuring total factor productivity (TFP). Section IV then compares TFP between Brazil and the United States, and section V sets forth final thoughts.

\section{II}

\section{Agricultural development in Brazil and the United States}

As a dynamic sector of the Brazilian economy, agriculture makes a major contribution to gross domestic product (GDP) and to the country's exports; and it also generates employment and produces food and energy (Vieira Filho, 2014).

Nonetheless, it is heterogeneous in terms of modernization, according to the description made by Paiva (1971), who outlined the agricultural modernization process and its technological dualism or multiplicity. In some more economically developed regions, the percentage of modern farmers is always very high compared with the other categories. In contrast, in regions referred to as "backward", the proportion of traditional farmers predominates or is even total. Between these two extremes, however, there are developing regions that display varying degrees of modernization. Apart from the differences between regions, Paiva (1971) also draws attention to disparities in the degree of modernization between the products of a given region.

Modernization changes production relations by increasing capital and forging links between agriculture and other sectors, such as manufacturing industry or agribusiness. ${ }^{2}$ It is defined as the technical transformation of farming in the post-war period, based on imports of tractors and fertilizers in an effort to raise productivity (Graziano da Silva, 1996, p. 19).

2 On the green revolution, see Chianca (2004) and Fuck and Bonacelli (2007). 
Public policies, particularly towards rural credit, also gave many producers the opportunity to use more modern resources in agriculture; but not all farmers had access to them. The change in the technical basis of agriculture increases the need for investment, so credit becomes essential for gaining access to more modern technologies. Ciprandi and Fert Neto (1996) show that, in Brazil, public policies giving incentives to modernization mainly benefited large and medium-scale owners.

Other factors, such as the opening of markets to trade, forced many producers to improve their production and management techniques to be able to compete with the imported products. Coura, Figueiredo and Santos (2006) noted that the technical efficiency of certain crops (such as cotton, rice, beans, maize and soya) increased following the liberalization of the Brazilian economy, particularly after the introduction of the real in 1994. These authors highlight the fact that São Paulo agriculture reacted to the greater external competition caused by liberalization, combined with the appreciation of the national currency and increasing productivity. The benefits were not distributed uniformly between the different regions, however, with the largest gains clearly concentrated in the regions that receive more support from technical assistance and rural extension services.

In addition to trade liberalization, burgeoning demand driven by the growth of many developing countries elicited greater production of food and raw materials, and provided an opportunity for producers to improve efficiency and make profits in those "emerging" markets. According to Wilkinson (2010), demand from emerging countries has given a second wind to the life cycle of the key commodities. In recent years, the financial sector has also become more involved in agribusiness. In the case of grains and oilseeds, new financial instruments have been designed to support the futures market and provide advance financing. Large traders have also become more involved in harvest financing.

Some Brazilian crops display productivity patterns that are similar to those of global benchmark countries. Gasques, Bastos and Bacchi (2008) describe how the TFP of Brazilian agriculture (which is the ratio of the sum of all outputs to the sum of all inputs) has grown at high and rising rates over the last 30 years. These authors estimate average annual growth in that period at $2.51 \%$, which is higher than the rate reported for the United States by Ball (2006).

Agriculture in the United States is characterized by high productivity, the adoption of technologies and extensive farmed areas, which make that country one of the world's largest crop producers. In 2010, for example, it was the largest producer of maize, ahead of China and Brazil, and the largest soya producer, followed by Brazil. ${ }^{3}$

The high productivity indices achieved by the United States agriculture sector have become benchmarks for many countries. Nonetheless, the adoption of technologies and modernization occurred in earlier periods than in Brazil. This is particularly true of labour-saving technologies, as noted by Hayami and Ruttan (1988) when comparing the United States, where such technologies were adopted owing to labour scarcity in the countryside, with Japan, which introduced technologies that economized on land, since this was the scarcest resource in that country. ${ }^{4}$

According to Fuglie, MacDonald and Ball (2007), the amount of labour employed in the agriculture sector declined rapidly in the 1950s, 1960s and 1970s in the United States, owing to the increase in inputs (new agricultural machinery and improved chemical inputs) and, mainly, the reduction in farm labour, since the increase in labour costs encouraged farmers to adopt technologies. The change began with an improvement in the quality of inputs (including machines) and chemical products, with new modes of application, which in many cases reduced the chemical load per hectare without compromising crop yield. Moreover, larger scale and integration between rural producers, input suppliers, and processors have improved practices in animal husbandry, among other areas.

Innovations, particularly in the agricultural machinery industry, were decisive for the expansion of the sector in the west of the United States during the nineteenth century, mainly through labour-saving technologies. In addition to production innovations, new production arrangements were already changing the country's farming in the 1950s, such as the integration of the agriculture sector with input manufacturers and agribusiness (Sunding and Zilberman, 2000). As noted by Alves (2010), chemical-biological technologies, such as inputs that increase land yields, also have potential to enhance labour productivity, or output per worker, which thus depends on both biochemical and mechanical technology.

The greater interaction between agriculture and other sectors in the United States in the 1950s was already displaying the decline in agricultural production (dentro

\footnotetext{
${ }^{3}$ For further details, see FAO (2012).

4 For a critical review of the literature and the role of learning economies see Vieira Filho and Silveira (2012). The authors work with the technological diffusion model, productive dualism and induced innovation, incorporating elements of technological competition (Vieira Filho, Campos and Ferreira, 2005), and agents' learning (Vieira Filho and Silveira, 2011) into the debate.
} 
da porteira $)^{5}$ relative to GDP. According to Davis and Goldberg (1957), the term "agribusiness" was defined as the sum of operations involved in input purchase and the production and distribution of agricultural products, because in that period, there was a closer relation between agricultural activity and the production chain antes $d a$ porteira and depois da porteira (industry and trade that supply inputs for rural production and the purchase, transport, processing and sale of agricultural products, to the final consumer, respectively).

For Dimitri, Effland and Conklin (2005), technological evolution in United States agriculture began in the postWorld War II period; and low-cost chemical fertilizers and pesticides have been used since 1945. Simultaneously, progress was made in terms of the genetic improvement of plants and animals and in mechanization, which made

5 The term "dentro da porteira" encompasses everything relating to agricultural production: planting, management, office, yields, machine maintenance, input storage, disposal of containers, and labour. "Antes da porteira" refers to everything necessary for agricultural production but is not present on the farm, which the farmer has to purchase to be able to produce: all inputs (machines, chemical agents, fertilizers, seeds and others). "Depois da porteira" refers to storage and distribution, including logistics. agricultural activity more profitable. In the late 1960s, mechanized harvesting was adopted in crops such as sugar beet, cotton and tomatoes; and in 1970, tractors replaced animal power. Since 1900, new technologies and rural infrastructure development have strengthened and increased the links between farmers and labour and capital markets, and with many services. ${ }^{6}$

When analysing the evolution of agricultural productivity in Brazil and the United States, differences can be observed through time; and it is important to remember that the initial phase of comparison is different, because the modernization process in each country did not occur at the same time. In this case, following the ECLAC tradition, Rodríguez (1977) shows that many technologies were developed and adopted in the more developed countries (centre), and some of them later spread to the less developed countries (periphery).

\footnotetext{
${ }^{6}$ It is worth noting transport costs which directly affect factor use (labour, land and type of technology) in the two countries. See, for example, Chomitz and Gray (1996) and Cropper, Puri and Griffiths (2001). To some extent this is an important aspect that is not fully captured by the adopted methodologies.
}

\section{III}

\section{Method of analysis: measurement of TFP}

The growth of TFP is the difference between the effective growth rate of production and the growth rate of the factors of production, assuming no technological change or improvement in producer efficiency. Output growth can indicate two different situations: one reflecting an increase in the physical quantity of inputs used in the production process, and another resulting from a more efficient use made of the factors of production in the process. The latter is TFP growth.

According to Sadoulet and De Janvry (1995), TFP is the most common measurement of technical progress, defined as a ratio between output and an index of all inputs. For Pires and Garcia (2004), changes in allocative efficiency play a fundamental role, even more important than the technological gap, in explaining productivity differences between developed and developing countries. Jorgenson (1996) and Christensen (1975) seek to provide details of the concepts and construction of the index that evaluates this productivity measure. Gasques and others (2010) have calculated this indicator with respect to Brazil.
According to those authors, the Tornqvist index, which is used to calculate TFP, is a discrete approximation to the Divisia Index (Chambers, 1998) and the most appropriate tool for analysing economic variables, since the data are available in discreet form, thus:

$$
\begin{gathered}
\ln \left(\frac{P T F_{t}}{P T F_{(t-1)}}\right)=\frac{1}{2} \sum_{i=1}^{n}\left(S_{i t}+S_{i(t-1)}\right) \ln \left(\frac{Y_{i t}}{Y_{i(t-1)}}\right) \\
-\frac{1}{2} \sum_{j=1}^{m}\left(C_{j t}+C_{j(t-1)}\right) \ln \left(\frac{X_{j t}}{X_{j(t-1)}}\right)
\end{gathered}
$$

Where $Y_{i}$ and $X_{j}$ are the amount produced and the volume of inputs used, respectively; whereas $S_{i}$ and $C_{j}$ refer to the proportion of product $i$ in the total value of production and the portion of input $j$ in total input cost.

The left-hand side of the equation defines the variation of TFP over two successive time periods; while the right-hand side contains two terms. The first is the logarithm of the ratio of quantities in two periods of time, 
weighted by the average proportion of each product in total output value. The second is the logarithm of the ratio of input quantities in the same period, also weighted by the average proportion of each input in total cost.

Consequently, calculation of the Tornqvist index requires the prices and quantities of all products and inputs used. The variation in TFP is calculated by an exponential function. To attain the TFP index for each year, a base year is chosen for which the index value is set at 100 , and it is then chained with subsequent years. This chaining process can be studied in Hoffmann (1980).

According to MAPA/AGE (2011) and Gasques and others (2014), two types of indices must be measured to calculate TFP: (i) aggregate output, and (ii) aggregate input. The first used data on permanent and seasonal crops, and on animal production and slaughter. The index encompassed 66 crop products ( 31 seasonal and 35 permanent) and 11 livestock activities (eight products from animal breeding and three types of meat — beef, pork, and chicken-). Data from the Brazilian Geographical and Statistical Institute (IBGE), on the values and quantities are based on the Municipal Agricultural Output Surveys (PAM) and Municipal Livestock Production Surveys (PPM). The figures for the weight of carcasses were taken from the IBGE Quarterly Survey of Animal Slaughter. The prices were obtained from the survey conducted by the Getulio Vargas Foundation.

The aggregate input index is formed by three components: land (crops and pastures), labour (personnel employed) and capital (machines, pesticides and fertilizers). In the case of land, the data on areas cultivated were taken from the PAM survey, and those on grazing area from the IBGE agricultural censuses. Statistics for the inter-census years were calculated by interpolation using growth rates. Land prices and rents are obtained from the Getulio Vargas Foundation. Labour market data (persons aged 15 years or older employed in agricultural activities) and wages were taken from the IBGE National Household Survey (PNAD). In the case of capital, the quantities of motorized agricultural machinery used were obtained from the yearbook of the National Association of Motor Vehicle Manufacturers (ANFAVEA), and the values of sales by firms with units and spare parts sold domestically.

The depreciation period considered was 16 years. Thus, every 16 years, the number of units existing up to that year is subtracted from the number of units sold, so that the result gives the stock of machines during the year. Data on fertilizer and pesticide consumption were obtained by requests. In the case of fertilizers, information was requested from Potafos and the National Association for Fertilizer Diffusion (ANDA), whereas in the case of pesticides, the National Union of the Industry of Agricultural Defence Products (SINDIVEG) was contacted.

To calculate the indices, it is not necessary to deflate the values of outputs and inputs, because the calculation uses annual shares. The period studied spans 1975 to 2010. In the case of the United States, the statistics were obtained from the Economic Research Service (ERS) of the United States Department of Agriculture (USDA). The Brazilian statistics were calculated using the same formula and methodology as applied by USDA, specifically to provide a good basis for comparison. It should be noted that the period studied is quite long and both the Brazilian and United States economic structures changed significantly in that time. Nonetheless, this does not invalidate the comparative study. Among studies that make various international comparisons of TFP, the reader can consult the volume produced by Fuglie, Wang and Ball (2012). Brazilian TFP growth was one of the fastest among the various countries analysed, as can also be seen in the following comparative analysis with the trend in the United States.

\section{IV}

\section{Comparison of TFP between Brazil}

\section{and the United States}

\section{Evolution and overview}

Although the initial phase of TFP analysis in a sector such as agriculture or in the production of a crop can vary from one country to another, the aim of this article is to determine whether the gaps or differences between Brazil and the United States have widened or narrowed through time. As the historical series analysed runs from 1975 to 2013, the production structures in both countries are very different between the start and end of 
that period, and the two economies must be compared in that context.

The productivity of the Brazilian agriculture sector has been evaluated in many studies, including Gasques and Conceição (2000); Gasques, Villa Verde and Oliveira (2004); Gasques, Bastos and Bacchi (2008), and Gasques and others (2010). The main specific analyses of the evolution of United States agricultural activity based on TFP calculations are those made by ERS/USDA. Nonetheless, there are no comparative studies of the evolution of the two countries to determine whether the gaps are increasing or decreasing through time. The current study chose to make the comparison with the United States because this country displays high productivity indices, maintains a considerable volume of agricultural production, and is considered a world leader in the production of many crops.

The TFP indices measure aggregate output per unit of aggregate input, and thus provide a guide to the efficiency of agricultural production (Thirtle and Bottomley, 1992). Few studies have calculated TFP by crop, owing to the difficulty of controlling for specific levels of input and output. The fact that inputs are often shared in a given production unit makes it difficult to assign inputs to a specific crop. For example, the methodology of the Brazilian agricultural census itself collects data on inputs, labour and output by establishment, and not by crop. For this reason, the comparison approach is by agricultural sector.

Before comparing the trend of TFP in Brazilian and United States agriculture, it is worth reviewing the trend of that indicator in other regions of the world. Figure 1 shows the TFP of countries of Latin America and the Caribbean, including Brazil, compared with that of other regions and country groupings, including high-income countries such as the United States. The high-income group registered the highest average TFP growth from 1961 to 2007; and this was followed by Latin America and the Caribbean, where growth was actually above the world average. Ludena (2010) highlights the strong economic performance of the region with respect to other developing regions: after 1980, efficiency increased and the gap with respect to high-income countries such as the United States narrowed.

FIGURE 1

Annual TFP growth in agriculture, weighted average, 1961-2007

(Percentages)

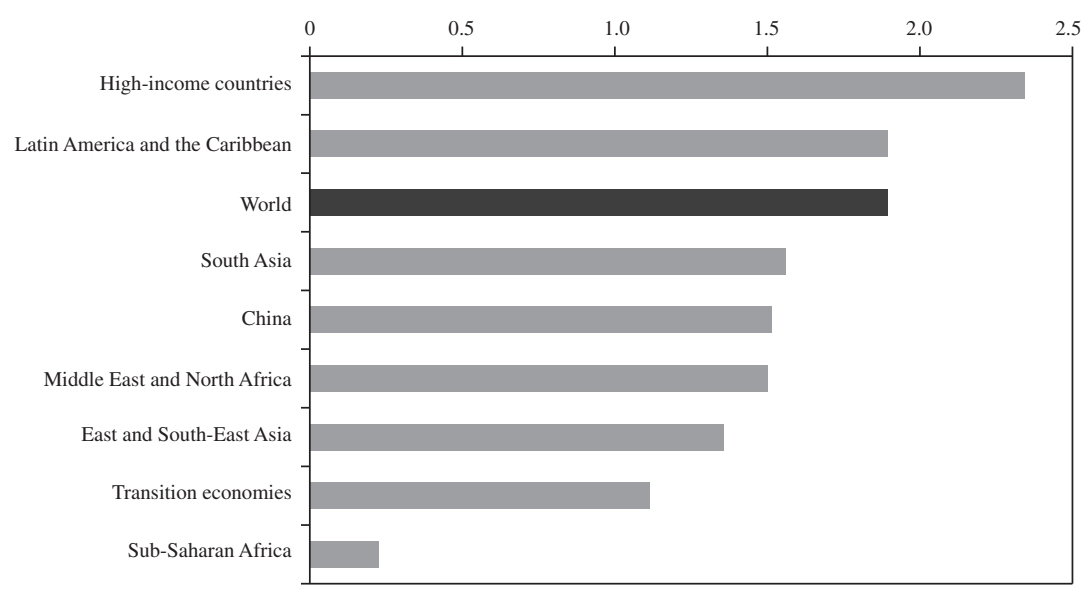

Source: C.E. Ludena, "Agricultural productivity growth, efficiency change and technical progress in Latin America and the Caribbean", IDB Working Paper Series, No. 186, Washington, D.C., Inter-American Development Bank, 2010.

Table 1 reports data on agricultural output growth and agricultural TFP between 1961 and 2007, with a breakdown by decade and for the whole period studied. For that purpose, all developing countries were taken as the reference. Although data are available for Latin America and the Caribbean, for a closer analysis of
Brazil, the study focused on the group of countries referred to as the north-east of South America, namely Brazil followed by French Guyana, Guyana and Suriname. The figure shows the evolution of all developed countries, particularly the United States and Canada. 
The group that includes Brazil recorded major growth in both agricultural production and TFP, except for a few periods such as 1961 to 1979 , in which TFP did not increase. In the other periods, productive growth surpassed that of other developed countries and that of the group consisting of the United States and Canada. The strongest TFP growth in the north-east of South America - which includes Brazil- occurred in the 1980 s, when average growth rates outpaced those of the rest of Latin America and the Caribbean.

The analysis of TFP in Brazil alone reveals a larger increase in later years compared with the longer series covering the 1970s and 1980s. In table 2, Gasques, Bastos and Bacchi (2008) list the main studies of TFP in Brazil and the United States.

The stronger growth of TFP in more recent periods confirms studies that describe how Brazilian agriculture has moved towards new agricultural frontiers. Grain production in the centre-west, benefiting from the use of modern inputs and mechanization, is an example. According to Yokoyama and Igreja (1992), the share of soya from that region in Brazilian agriculture increased from just $4 \%$ of the cultivated area in 1975 to $28 \%$ in 1985 .

TABLE 1

Regions of the world: agricultural output and productivity growth by decade, 1961-2007

(Percentages, annual average throughout the period)

\begin{tabular}{|c|c|c|c|c|c|c|c|c|c|c|c|c|}
\hline \multirow[b]{2}{*}{ Periods } & \multicolumn{6}{|c|}{ Growth of agricultural output } & \multicolumn{6}{|c|}{ Growth of agricultural TFP } \\
\hline & $\begin{array}{l}1961- \\
1969\end{array}$ & $\begin{array}{l}1970- \\
1979\end{array}$ & $\begin{array}{l}1980- \\
1989\end{array}$ & $\begin{array}{l}1990- \\
1999\end{array}$ & $\begin{array}{l}2000- \\
2007\end{array}$ & $\begin{array}{l}1961- \\
2007\end{array}$ & $\begin{array}{l}1961- \\
1969\end{array}$ & $\begin{array}{l}1970- \\
1979\end{array}$ & $\begin{array}{l}1980- \\
1989\end{array}$ & $\begin{array}{l}1990- \\
1999\end{array}$ & $\begin{array}{l}2000- \\
2007\end{array}$ & $\begin{array}{l}1961- \\
2007\end{array}$ \\
\hline All developing countries & 3.16 & 2.82 & 3.47 & 3.65 & 2.99 & 3.23 & 0.18 & 0.54 & 1.66 & 2.3 & 1.98 & 1.35 \\
\hline Latin America and the Caribbean & 3.11 & 3.07 & 2.39 & 2.92 & 3.23 & 2.92 & 0.29 & 0.7 & 1.2 & 2.54 & 2.6 & 1.47 \\
\hline $\begin{array}{l}\text { North-East of South America } \\
\text { (mainly Brazil) }\end{array}$ & 3.56 & 3.82 & 3.7 & 3.31 & 4.05 & 3.68 & -0.52 & -0.76 & 3.08 & 3.81 & 3.63 & 1.87 \\
\hline All developed countries & 2.08 & 1.86 & 0.88 & 1.16 & 0.17 & 1.24 & 1.21 & 1.52 & 1.47 & 2.13 & 0.86 & 1.48 \\
\hline United States and Canada & 2.05 & 2.17 & 0.73 & 2.04 & 1.04 & 1.61 & 0.86 & 1.37 & 1.35 & 2.26 & 0.33 & 1.29 \\
\hline
\end{tabular}

Source: K.O. Fuglie, "Total factor productivity in the global agricultural economy: evidence from Fao data", The Shifting Patterns of Agricultural Production and Productivity Worldwide, J.M. Alston, B.A. Babcock and P.G. Pardey (eds.), Iowa, Iowa State University, 2010. Note: TFP: Total factor productivity.

TABLE 2

Brazil and the United States: annual productivity growth in agriculture (Percentages)

\begin{tabular}{lcc}
\hline Regions & $\begin{array}{c}\text { Total factor } \\
\text { productivity (TFP) }\end{array}$ & Studies \\
\hline São Paulo (1995-2002) & 2.48 & (Vicente, 2003) \\
United States (1999-2002) & 1.38 & (Ball, 2006) \\
Brazil (1975-2005) & 2.51 & (Gasques, Bastos and Bacchi, 2007) \\
Brazil (2000-2005) & 3.87 & (Gasques, Bastos and Bacchi, 2007) \\
\hline
\end{tabular}

Source: J.G. Gasques, E.T. Bastos and M.R.P. Bacchi, "Produtividade e fontes de crescimento da agricultura brasileira", Políticas de incentivo à inovação tecnológica, J.A. de Negri and L.C. Kubota (eds.), Brasilia, Institute of Applied Economic Research (IPEA), 2008. 
Table 3 reports growth indices in selected periods to compare the trends of other factors, such as land and labour productivity. The latter, or output per worker, depends on both biochemical and mechanical technology. Vieira Filho and Silveira (2011) stress the importance of knowledge, which can be used to improve production techniques. That knowledge may be either tacit or based on research conducted by institutions such as the Brazilian Agricultural Research Enterprise (EMBRAPA).

TABLE 3

Brazil: annual growth rates, 1970-2006 and 1995-2006

(Percentages)

\begin{tabular}{lcc}
\hline Indicators & $1970-2006$ & $1995-2006$ \\
\hline Output index & 3.483 & 3.138 \\
Input index & 1.189 & 0.991 \\
TFP & 2.267 & 2.126 \\
Productivity of land & 3.316 & 3.158 \\
Productivity of labour & 3.528 & 3.409 \\
\hline
\end{tabular}

Source: J.G. Gasques, "Produtividade total dos fatores e transformações da agricultura brasileira: análise dos dados dos censos agropecuários", A agricultura brasileira: desempenho, desafios e perspectivas, J.G. Gasques, J.E.R. Vieira Filho and Z. Navarro (orgs.), Brasilia, Institute of Applied Economic Research Aplicada (IPEA), 2010.

Note: TFP: Total factor productivity.

When a section is taken of the trend of the indices between 1970-2006 and 1995-2006, it can be seen that output growth is mainly due to the increase in TFP and that labour productivity growth outpaced that of land in both periods. Nonetheless, as noted by Gasques and others (2010), labour productivity is measured on a gross basis, and its main component is the productivity of the land. Thus, the use of a land-economizing technology, such as fertilizer, can help improve labour productivity, since operations such as harvesting can be done with fewer people and machines.

As shown by Sunding and Zilberman (2000), the modernization process in the United States, involving the adoption of land- and labour-saving technologies, began in the 1950s, much earlier than in Brazil, where this occurred in the ensuing decades.

Figure 2 shows the trend of the indices of inputs, output and TFP in the United States from 1948 to 2009. The agricultural inputs index varies little, so TFP growth reflects a higher level of output. According to Gasques and others (2010), a variety of factors, including agricultural research, play a major role in productivity growth. Better allocation of resources -including more modern technologies that reduce losses in the use of inputs, such as fertilizers with less leaching, biological nutrient fixing, improved varieties, cumulative knowledge and learning - makes it possible to increase output with fewer inputs.

There are many factors that enhance efficiency in resource management in agricultural activity and help optimize their use. Agricultural research by public and private enterprises is important for creating technological innovations, generally through new production processes. As noted by Vieira Filho (2009), the practice of direct seeding into stubble, which is widely used in Brazil for cereal cropping, is the fruit of that interaction in which learning plays a major role. Technological change, such as direct seeding or fertilizer with a higher level of absorption by the plants, makes it possible to produce more (higher productivity) using fewer inputs. Coelli and Prasada Rao (2005) state that the differences in access to certain factors (fertilizers, tractors, animals and irrigation, among others) can generate productivity differences between countries. Moreover, Ruttan (2002) draws attention to a number of problems faced by farmers around the world that alter agricultural productivity, such as soil degradation and loss; flooding and salinity; the joint evolution of pests, pathogens and hosts; and climate change. 
FIGURE 2

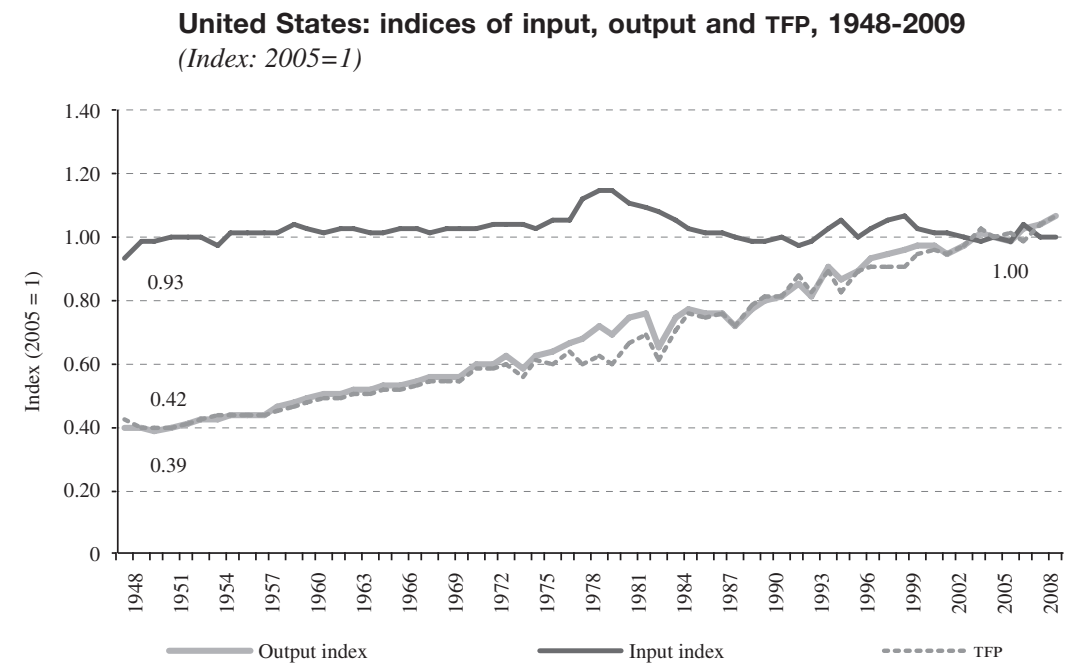

Source: United States Department of Agriculture, “Agricultural Productivity in the U.S.”, Economic Research Service, 2012 [online] http:// www.ers.usda.gov/Data/AgProductivity.

Note: TFP: Total factor productivity.

Table 4 displays the main sources of agricultural growth in the United States from 1948 to 2009. The fact that the labour indicator was negative in all periods, means less labour was used.

The output index was positive throughout the series; and in some periods — such as 1966-1979- was the fastest growing. In the case of land, there were no major variations through time. Capital grew most between 1948 and 1953, when, according to Sunding and Zilberman
(2000), United States farmers started to use technology more intensively (agricultural machines and fertilizers), and this meant a larger need for capital. Except between 1979 and 1990 and in the most recent period (20072009), the source referred to as materials, or entry of materials, which encompasses energy, fertilizer and chemical use, displays rising values. This shows that United States agriculture increasingly uses products from other sectors, such as industry.

TABLE 4

United States: sources of growth in the agriculture sector and average annual growth rates, 1948-2009

(Percentages)

\begin{tabular}{lrrrrrrrrrrrrr}
\hline & $1948-$ & $1948-$ & $1953-$ & $1957-$ & $1960-$ & $1966-$ & $1969-$ & $1973-$ & $1979-$ & $1981-$ & $1990-$ & $2000-$ & $2007-$ \\
& 2009 & 1953 & 1957 & 1960 & 1966 & 1969 & 1973 & 1979 & 1981 & 1990 & 2000 & 2007 & 2009 \\
\hline Output & 1.63 & 1.18 & 0.96 & 4.03 & 1.21 & 2.24 & 2.65 & 2.26 & 1.54 & 0.96 & 1.84 & 0.77 & 1.88 \\
Input & 0.11 & 1.34 & 0.28 & 0.50 & 0.05 & -0.08 & 0.46 & 1.64 & -1.85 & -1.22 & 0.31 & 0.14 & -1.80 \\
Sources & & & & & & & & & & & & & \\
Labour & -0.52 & -0.81 & -1.08 & -0.83 & -0.81 & -0.61 & -0.38 & -0.19 & -0.22 & -0.43 & -0.34 & -0.35 & -0.64 \\
Capital & 0.02 & 0.54 & 0.15 & 0.03 & 0.08 & 0.32 & 0.14 & 0.32 & 0.23 & -0.61 & -0.21 & 0.05 & 0.35 \\
Land & -0.08 & 0.02 & -0.17 & -0.16 & -0.07 & -0.22 & -0.29 & 0.00 & -0.12 & -0.09 & 0.00 & -0.08 & -0.12 \\
Materials & 0.69 & 1.58 & 1.38 & 1.45 & 0.85 & 0.43 & 0.99 & 1.50 & -1.74 & -0.09 & 0.87 & 0.52 & -1.39 \\
TFP & 1.52 & -0.16 & 0.68 & 3.53 & 1.16 & 2.32 & 2.19 & 0.62 & 3.39 & 2.19 & 1.53 & 0.63 & 3.68 \\
\hline
\end{tabular}

Source: United States Department of Agriculture, "Agricultural Productivity in the U.S.”, Economic Research Service, 2012 [online] http:// www.ers.usda.gov/Data/AgProductivity.

Note: TFP: Total factor productivity. 
Brazilian agriculture has grown at rates similar to, or even faster than, those in the United States, so the gap between the two countries has narrowed. Nonetheless, the factor composition is not the same, because they are in different stages of agricultural evolution. Ludena (2010) advises cautious interpretation, because the development levels of the countries are different. For example, the study by Alauddin, Headey and Prasada Rao (2005) shows that TFP in Brazil in 1970 was half that of the United States. Climate factors can cause reduce output, which in turn causes a fall in TFP. Changes in price expectations on markets can encourage or discourage an activity, and can even lead to its replacement by others that are productively less efficient.

\section{Comparison framework: reducing the productivity gap}

Measuring the international productivity gap entails comparing national productivity against the international benchmark, which in this case is United States agriculture because of the technology applied and for its high productivity indices. Figure 3 compares the Brazilian TFP with that of the United States. Brazilian TFP growth outpaced that of the United States after 1975, so the productivity gap between the two countries narrowed.

At the end of the period studied the indices stood at 3.67 in Brazil (2010) and 1.75 in the United States (2008), so the former grew by $267 \%$ and the latter by $75 \%$. The changes that led to a sharp increase in productivity in United States agriculture occurred between 1950 and 1970. In Brazil, the modernization process started with the importation of agricultural machinery in the 1950s, but it was only in the 1970s that productivity started to grow significantly, particularly with the planning of agricultural research. In addition, the expansion of the agricultural frontier in Brazil occurred as from 1970, which probably differs from what happened in the United States.

FIGURE 3

Brazil and the United States: TFP indices, 1975-2010

(Index: 1975=1)

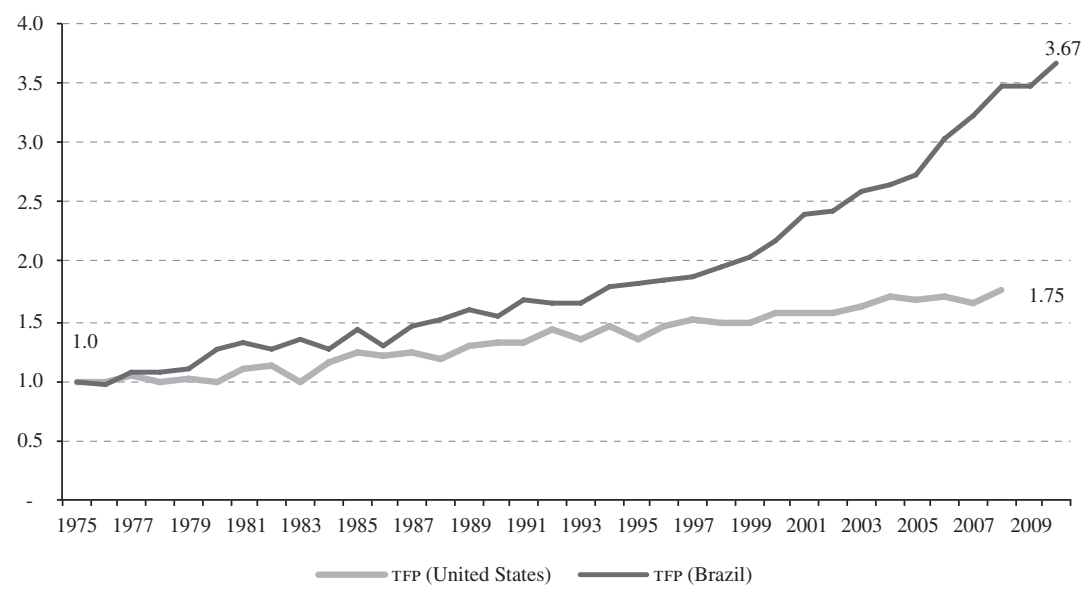

Source: United States Department of Agriculture, Total Factor Productivity, Washington, D.C., Economic Research Service, 2008; and Ministry of Agriculture, Livestock and Food Supply, Produtividade total dos fatores, Brasilia, 2011.

Note: TFP: Total factor productivity.

The study conducted by the Organization for Economic Cooperation and Development (OECD, 2011) reports statistics on TFP growth rates in various regions of the world. While the rate tends to decline in the developed economies, dropping from $1.48 \%$ per year in $1961-2007$ to $0.86 \%$ per year in $2000-2007$, it has trended up in developing countries, from $1.35 \%$ per year in $1961-2007$ to $1.98 \%$ per year in $2000-2007$.

Figure 4 compares Brazil's TFP and input and output indices with those of the United States. This 
makes it possible to determine whether output growth reflects more intensive input use or the incorporation of efficiency-enhancing technology.

In the period studied, the input index for agricultural production remained broadly stable (rising by just $5 \%$ ) whereas the output index rose by $284 \%$. Most of the increase in output was due to technological changes, which means that more is being produced with fewer resources. According to the data reported, the annual average growth rate of TFP in Brazil between 1975 and 2010 was $3.6 \%$, compared with $1.9 \%$ in the United States. ${ }^{7}$ The input index in that country declined by $7 \%$, dropping from 1.00 in 1975 to 0.93 in 2008. Nonetheless, output and TFP grew by $62 \%$ and $75 \%$, respectively, so again more was produced with less.

${ }^{7}$ See comparisons in Ball (2006) and Gasques and others (2012).

FIGURE 4

Brazil and the United States: indices of input, output and TFP, 1975-2010 (Index: $1975=1$ )

A. United States

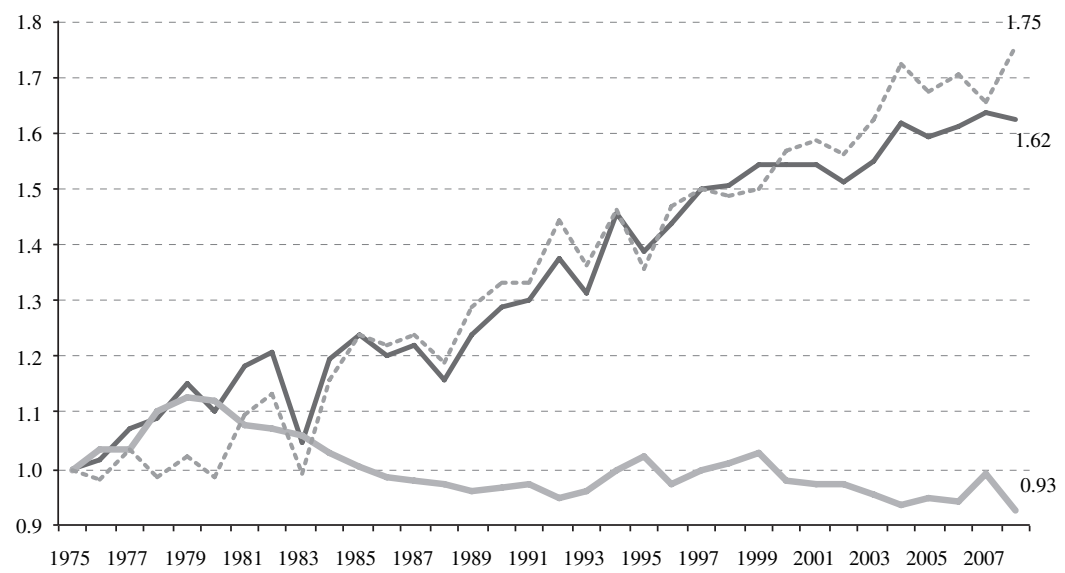

B. Brazil

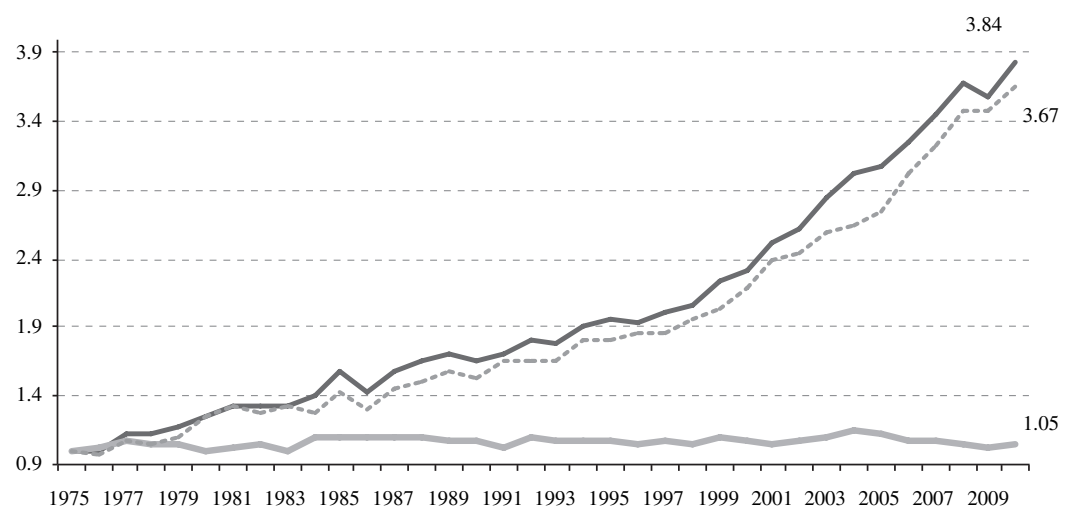

Output $\longrightarrow$ Input $\quad-\cdots-$ TFP

Source: United States Department of Agriculture, Total Factor Productivity, Washington, D.C., Economic Research Service, 2008; and Ministry of Agriculture, Livestock and Food Supply, Produtividade total dos fatores, Brasilia, 2011.

Note: TFP: Total factor productivity. 
Figure 5 compares the use of labour, land and capital in the production of the United States and Brazil. Although capital use grew in the United States economy between 1975 and 1981, the longer period 1975-2010 reveals a decrease in the use of all three factors. In the case of capital, the reduction occurs as from 1981. Ball and others (2001) note that capital use was important in United States agriculture between 1973 and 1981, but its importance declined between 1982 and 1993 since net fixed capital investment was negative in that latter period. This suggests that the obsolescence of the capital stock, perhaps owing to the high price of energy, could hold back productivity growth.

FIGURE 5

Brazil and the United States: indices of production factors (labour, land and capital), 1975-2010

(Index: 1975=1)

A. United States

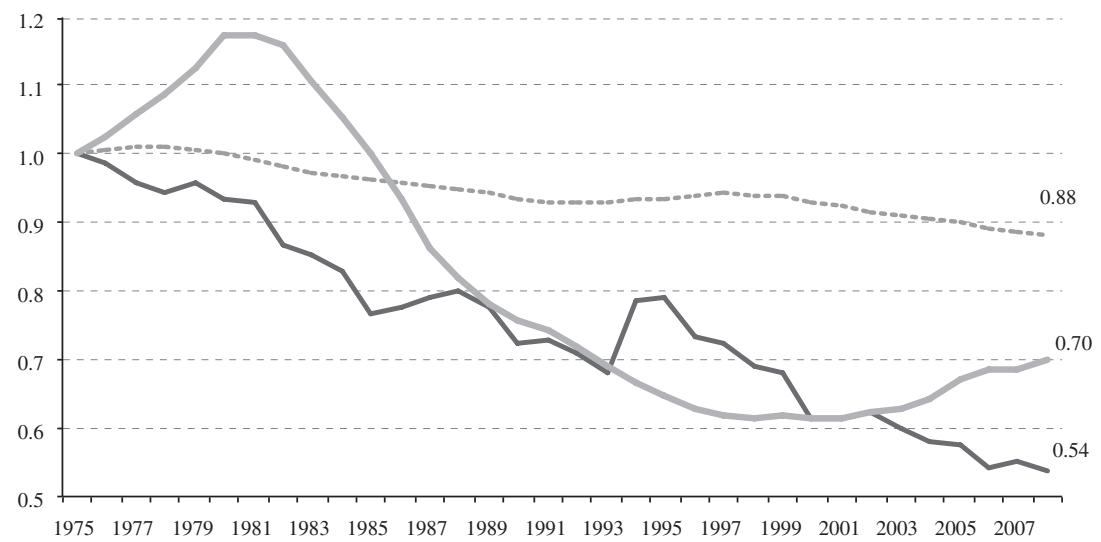

B. Brazil

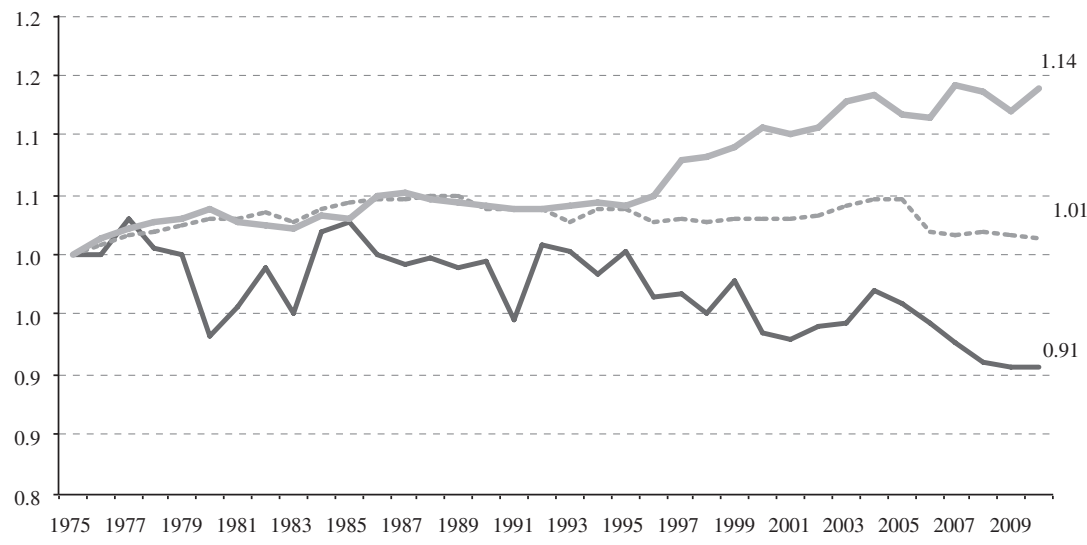

Labour $\quad \ldots \ldots \ldots$ Land $\quad$ Capital

Source: United States Department of Agriculture, Total Factor Productivity, Washington, D.C., Economic Research Service, 2008; and Ministry of Agriculture, Livestock and Food Supply, Produtividade total dos fatores, Brasilia, 2011. 
The reduction of capital intensity in the United States economy is another sign of technological progress, since, as noted above, the output index trended upwards in the same period. In Brazil, there was strong capital growth throughout the period. The incorporation of new agricultural frontiers in the latter part of the 1980s, relative stabilization in land use as from the 1990s, and a considerable reduction in the labour factor as from 1990. Capital grew and labour declined particularly in those years, coinciding with trade liberalization and greater private investment in agriculture.

The rise in the capital index is associated with the creation of programmes of financing and investment in Brazilian agriculture as from the second half of the 1990s. These included the National Programme for Strengthening Family Farming (PRONAF), followed by the Programme to Modernize the Agricultural Tractor Fleet and Harvester Tools (MODERFROTA). These programmes were fundamental for the modernization and technological progress of capital in Brazilian agriculture, and led to a $14 \%$ increase in the period studied.

According to Gasques and others (2010, p. 35), the higher productivity of land in Brazil was a result of increased research expenditure, particularly by EMBRAPA, and the incorporation of new areas with higher productivity in part of the reference period spanning more than 30 years. The authors state that the higher productivity of land also reflects innovations made in production processes, including agricultural research, the direct seeding system, inoculation with bacteria, integrated pest management and the creation of varieties and species with sufficient flexibility to adapt to the different climatic and environmental conditions. Gasques and others (2013) show that the migration of crop production and livestock activity to new regions of the north, centre west and centre north-east, along with the quality of inputs used in agricultural activity, among other factors, also contributed to productivity growth.

University participation in agricultural research is also very important for Brazil. Teixeira, Clemente and Braga (2013) highlight the relevance of postgraduate research programmes in areas such as the improvement of plants and animals, soils and fertility, mechanization, plant and animal management, and in the creation of products that allow for the development of agribusiness in the country.

With regard to the convergence of agricultural productivity in Brazil with that of the United States, the gap between the two countries has narrowed. Brazilian agriculture has grown very strongly, becoming more productive and less labour-intensive, while the amount of land used has remained stable.

\section{Productive inequality of Brazilian agriculture ${ }^{8}$}

A comparison of the Brazilian agriculture sector with that of the United States reveals TFP convergence, thereby narrowing the productivity gaps between the two countries. Nonetheless, that convergence does not encompass all Brazilian farming, owing to the high degree of structural heterogeneity that exists in the production segment.

Although the TFP figures are convergent, Brazil's regional heterogeneity and complexity mean that not all of the agriculture sector is technologically up-to-date, so only part of the production sector benefits from the effects of modernization (Vieira Filho, 2012). As noted by Poudel, Paudel and Zilberman (2011), there may be convergence between regions within a country, but not throughout the national territory as a whole. This means that, despite convergence between certain regions, the growth indices within a given country can vary greatly, maintaining regional heterogeneities, which can also relate to crops and activities.

Fornazier and Vieira Filho (2012) and Vieira Filho, Santos and Fornazier (2013) find very pronounced productive heterogeneity in Brazilian agriculture in terms of income inequality; and Vieira Filho (2013) reaches a similar conclusion in an analysis of results for family farming.

Table 5 shows that farms can be subdivided into four income levels: extreme poverty and low, middle and high income. The results show that the middleand high-income groups, which account for less than $10 \%$ of farms, produced $85 \%$ of gross production value (GPV), while the $63 \%$ of farms that exist in conditions of extreme poverty produced less than $4 \%$ of total GPV. The Gini coefficient of production reported an indicator of high inequality, with a value close to 1 .

\footnotetext{
${ }^{8}$ The aim of this subsection is to briefly show that the productivity gains mentioned are incorporated in a different way in Brazil, particularly owing to the high productive concentration that exists there, which is reflected in regional and sectoral terms. An exhaustive investigation of these issues is beyond the scope of this article. For deeper and more detailed studies of the topic, see Fornazier and Vieira Filho (2012); Vieira Filho, Santos and Fornazier (2013).
} 
TABLE 5

Brazil: stratification of farm incomes by production, 2006

\begin{tabular}{|c|c|c|c|c|c|c|}
\hline Groups & $\begin{array}{l}\text { Minimum monthly } \\
\text { wage equivalent }^{\mathrm{a}}\end{array}$ & $\begin{array}{l}\text { Number of farms } \\
\text { (thousands) }\end{array}$ & Percentage & $\begin{array}{c}\text { Annual gross } \\
\text { production value (GPV) } \\
\text { (billions) }\end{array}$ & Percentage & $\begin{array}{l}\text { Gini } \\
\text { coefficient }\end{array}$ \\
\hline Extreme poverty & $(0-2)$ & 3242 & 69.6 & 6.5 & 3.9 & \\
\hline Low income & $(2-10)$ & 960 & 20.9 & 18.5 & 11.1 & \\
\hline Middle income & $(10-200)$ & 416 & 9 & 59.9 & 35.9 & 0.89 \\
\hline \multirow[t]{2}{*}{ High income } & $>200$ & 23 & 0.5 & 81.7 & 49 & \\
\hline & Total & 4641 & 100 & 166.7 & 100 & \\
\hline
\end{tabular}

Source: Brazilian Geographical and Statistical Institute (IBGE), Agricultural Census 2006, Rio de Janeiro.

a Minimum wage equivalent $=$ monthly gross production value $(\mathrm{VBP}) /$ monthly minimum wage .

The group that exists in conditions of extreme poverty, which consists of roughly 3.2 million farms, is at the margin of agricultural production and is excluded from all sectors of economic activity because it lacks basic productive organization structures (both microand macroeconomic).

The low-income group (960,000 farms) needs government assistance in the form of development policies and the invigoration of small-scale normally familybased production. These are farms of low technological content and little capacity to absorb external knowledge, compounded by shortcomings in the managerial and macroeconomic spheres. It is necessary to improve credit access for these producers and to encourage the use of new technologies. The government needs to improve access to technical assistance and develop public-domain research when the market does not provide this.

Lastly, agricultural wealth is concentrated in the middle- and high-income groups. For those groups, technological absorption capacity is a secondary problem, but a macroeconomic environment favourable to sales growth is fundamental. Public policies need to be oriented towards topics that go beyond macroeconomic aspects, focusing on stimulating competitiveness, promoting exports, agricultural insurance and improving the logistical distribution of the products.

The productivity difference of a crop in a given state or region also reflects TFP differences: in some regions, producers concentrate on crops that are better suited to the prevailing climate and soil conditions, and they achieve a better allocation of resources, such as inputs, which implies a variation in TFP. Gasques and others (2010) show that TFP in Brazilian agriculture posted annual average growth of $2.27 \%$ in 1970-2006, whereas growth was negative in some states, such as Amazonas (-0.902\% per year). In other cases, including Mato Grosso, growth was positive $(4.67 \%$ per year), in the same period. These results show that, while the gaps between countries may narrow, intra-regional differences within Brazil can persist. In the United States, there are also productivity differences between the states, as revealed in the statistics (USDA, 2012).

Public policies, together with investment in agricultural research, technical assistance, and rural outreach, can help farmers make better use of resources -in other words, obtain higher productivity using fewer resources-. In addition to increasing output, reduced input use in the agriculture sector can have effects that are desirable from the environmental, labour and public health standpoint, by improving optimization and reducing pressure on natural resources (Blandford, 2012).

This makes it possible to design public policies for specific regions and identify places where higher productivity can be obtained, for example through agro-climatic zoning. Nonetheless, policies to that end must take account of the different aspects environmental conservation and social integration in the labour market. 


\section{V}

\section{Final thoughts}

According to ECLAC (2010), there are many differences in development levels between countries and even within a given country or sector, which constitute structural heterogeneity. Nonetheless, the gaps can narrow with time and thus reduce that heterogeneity.

To measure the difference between countries or sectors, this study compared the trends of TFP in the Brazilian and United States agriculture sectors and found that the productivity gap is tending to narrow. Nonetheless, the modernization of agricultural activity and its linkage with other sectors of the economy (such as inputs) is taking place in different periods in the two countries. Consequently, the reduction does not necessarily mean that productivity indices in the two countries are converging, because other factors come into play - such as the level of cumulative knowledge in an activity - which can not only promote growth differences, but also ratify the existing distance.

The countries analysed here recorded an increase in TFP in a longer series, so that greater production was obtained with fewer inputs. To achieve this, land economizing technologies were used, such as fertilizers and other agrochemicals, alongside labour-saving technologies in the form of machinery and agricultural tools.

With the more intensive use of certain inputs and the substitution of technologies in favour of one or other resource in particular, the activities-productivity gap between countries can decline. Nonetheless, climate differences, or differences in the capacity to adopt certain technologies, among other factors, make it difficult for all to benefit from the productivity gains. Although the productivity gap between Brazil and the United States has narrowed, there are many differences within these countries. In other words, structural heterogeneity exists not only between developed countries and developing ones, but also within a given country or activity.
Public policies (such as investment in research and development (R\&D), technical assistance and rural extension) can help farmers improve their efficiency in food production and animal breeding, to obtain a return with fewer inputs and resources. In addition to increasing TFP, they also help to optimize these factors and reduce environmental problems.

Given the degree of regional heterogeneity and complexity, not all of the Brazilian agricultural sector is technologically up-to-date, so only a part of that sector benefits from the effects of modernization. A comparison of Brazilian agriculture with that of the United States shows convergence in TFP (or a reduction in the productivity gap), which reduces the productivity gaps between the two countries. Nonetheless, that convergence does not encompass all of Brazilian production, owing to the high degree of structural heterogeneity that exists and productive concentration between agents. Over the last few decades, Brazilian agriculture has grown rapidly, becoming more productive and less labour-intensive, while using a stable quantity of land. Nonetheless, there are still huge challenges in promoting stakeholder-inclusive development.

Structural heterogeneity prevents the most backward segments from participating productively in the fastest growing markets. From the standpoint of public policymaking, the study shows that the failure of inclusive development will persist until the structural disparities in Brazilian agriculture are overcome. There are micro- and macroeconomic problems that are differentiated according to the specifics of each production group; and these must also be taken into account when designing government policies to correct the failings and minimize the structural problems. 


\section{Bibliography}

Alauddin, M., D. Headey and D.S. Prasada Rao (2005), "Explaining agricultural productivity levels and growth: an international perspective", Discussion Paper, No. 2, Brisbane, University of Queensland.

Alves, E.O. (2010), "O que significam as medidas de produtividade da agricultura?", Revista de Economia e Agronegócio, vol. 8, No. 3.

Ball, V.E. (2006), "Productivity and output growth in U.S. agriculture", Agricultural Resources and Environmental Indicators, K. Wiebe and N. Gollehon (eds.), Washington, D.C., United States Department of Agriculture/Economic Research Service.

Ball, V.E. and others (2001), "Levels of farm sector productivity: an international comparison", Journal of Productivity Analysis, vol. 15 , No. 1, Springer.

Blandford, D. (2012), "The Contribution of Agriculture to Green Growth" [online] http://www.oecd.org/dataoecd/ 25/41/48258861.pdf.

Buainain, A.M. and others (orgs.) (2014), O mundo rural do Brasil no século 21: a formação de um novo padrão agrário e agrícola, Brasilia, Embrapa.

Chambers, R.G. (1998), Applied Production Analysis. A Dual Approach, Cambridge, Cambridge University Press.

Chianca, G.K. (2004), "A parceria entre a Embrapa e as organizações estaduais", Agroanalysis, vol. 24, No. 5, Rio de Janeiro.

Chomitz, K.M. and D.P. Gray (1996), "Roads, land markets, and deforestation: a spatial model of land use in Belize", The World Bank Economic Review, No. 10, Oxford, Oxford University Press.

Christensen, L.R. (1975), "Concepts and measurement of agricultural productivity", American Journal of Agricultural Economics, vol. 57, No. 5, Oxford University Press.

Ciprandi, O. and J. Fert Neto (1996), "As perspectivas da pequena produção familiar na agricultura", Ciência Rural, vol. 26, No. 1, Federal University of Santa María.

Coelli, T.J. and D.S. Prasada Rao (2005), "Total factor productivity growth in agriculture: a Malmquist index analysis of 93 countries, 1980-2000", Agricultural Economics, vol. 32, No. 1, International Association of Agricultural Economists.

Coura, R.M., A.M. Figueiredo and M.L. Santos (2006), "Eficiência e tecnologia na agricultura paulista entre 1985 e 2001", Organizações Rurais \& Agroindustriais, vol. 8, No. 2.

Cropper, M., J. Puri and C. Griffiths (2001), "Predicting the location of deforestation: the role of roads and protected areas in north Thailand", Land Economics, vol. 77, No. 2, Madison, University of Wisconsin Press.

Davis, J.H. and R.A. Goldberg (1957), A Concept of Agribusiness, Boston, Harvard University.

Dimitri, C., A. Effland and N. Conklin (2005), "The 20th century transformation of U.S. agriculture and farm policy", Economic Information Bulletin, No. 3, Economic Research Service.

ECLAC (Economic Commission for Latin America and the Caribbean) (2010), "Structural heterogeneity and productivity gaps: from fragmentation to convergence", Time for equality: closing gaps, opening trails (LC/G.2432(SES.33/3)), Santiago.

FAO (Food and Agriculture Organization of the United Nations) (2012), "Production/Crops", FAOSTAT [online] http://faostat.fao.org2012.

Fornazier, A. and J.E.R. Vieira Filho (2012), "Heterogeneidade estrutural no setor agropecuário brasileiro: evidências a partir do Censo Agropecuário de 2006”, Texto para Discussão, No. 1708, Brasilia, Institute of Applied Economic Research (IPEA)

Fuck, M.P. and M.B.M. Bonacelli (2007), "A necessidade de reorganização e de fortalecimento institucional do snpa no Brasil", Revista de Política Agrícola, vol. 16, No. 1, Brasilia.

Fuglie, K.O. (2010), "Total factor productivity in the global agricultural economy: evidence from fao data", The Shifting Patterns of Agricultural Production and Productivity Worldwide, J.M. Alston, B.A. Babcock and P.G. Pardey (eds.), Iowa, Iowa State University.
Fuglie, K.O., J.M. MacDonald and E. Ball (2007), "Productivity growth in U.S. agriculture", Economic Brief, No. 9, United States Department of Agriculture/Economic Research Service.

Fuglie, K.O., S.L. Wang and V.E. Ball (eds.) (2012), Productivity Growth in Agriculture: an International Perspective, Cambridge, Massachusetts, CABI.

Gasques, J.G. and others (2014), "Produtividade da agricultura: resultados para o Brasil e estados selecionados", Revista Política Agrícola, vol. 23, No. 3.

(2013), Produtividade e crescimento: algumas comparações, Brasilia, Ministry of Agriculture, Livestock and Food Supply.

(2012), "Produtividade da agricultura brasileira e os efeitos de algumas políticas", Brasilia, Ministry of Agriculture, Livestock and Food Supply, unpublished.

(2010), "Produtividade total dos fatores e transformações da agricultura brasileira: análise dos dados dos censos agropecuários", A agricultura brasileira: desempenho, desafios e perspectivas, J.G. Gasques, J.E.R. Vieira Filho and Z. Navarro (orgs.), Brasilia, Institute of Applied Economic Research (IPEA).

Gasques, J.G., E.T. Bastos and M.R.P. Bacchi (2008), "Produtividade e fontes de crescimento da agricultura brasileira", Políticas de incentivo à inovação tecnológica, J.A. de Negri and L.C. Kubota (eds.), Brasilia, Institute of Applied Economic Research (IPEA).

(2007), "Produtividade e fontes de crescimento da agricultura", August [online] ftp://ftp.sp.gov.br/ftpiea/congressos/congpal20807.pdf.

Gasques, J.G. and J.C.P.R. Conceição (2000), "Transformações estruturais da agricultura e produtividade total dos fatores", Texto para Discussão, No. 768, Brasilia, Institute of Applied Economic Research (IPEA).

Gasques, J.G., J.E.R. Vieira Filho and Z. Navarro (orgs.) (2010), A agricultura brasileira: desempenho, desafios e perspectivas, Brasilia, Institute of Applied Economic Research (IPEA).

Gasques, J.G., C.M. Villa Verde and J.A.F.G. Oliveira (2004), “Crédito rural e estruturas de financiamento. Brasília", Texto para Discussão, No. 1036, Institute of Applied Economic Research (IPEA).

Graziano da Silva, J.F. (1996), A nova dinâmica da agricultura brasileira, Campinas, Institute of Economics/State University at Campinas (UNICAMP).

Hayami, Y. and V. Ruttan (1988), Desenvolvimento agrícola: teoria e experiências internacionais, Brasilia, Embrapa.

Hoffmann, R. (1980), Estatística para economistas, São Paulo, Pioneira IBGE (Brazilian Geographical and Statistical Institute) (2006), Censo Agropecuário 2006, Rio de Janeiro.

Jorgenson, D.W. (1996), "The embodiment hypothesis", Productivity, vol. 1, Cambridge, Massachusetts, The MIT Press.

Ludena, C.E. (2010), "Agricultural productivity growth, efficiency change and technical progress in Latin America and the Caribbean", IDB Working Paper Series, No. 186, Washington, D.C., Inter-American Development Bank.

MAPA/AGE (Ministry of Agriculture, Livestock and Food Supply/ Strategic Management Assessment) (2011), Produtividade total dos fatores, Brasilia.

Nohlen, D. and R. Sturm (1982), "La heterogeneidad estructural como concepto básico en la teoría de desarrollo", Revista de Estudios Políticos, No. 28.

OECD (Organization for Economic Cooperation and Development) (2011), Fostering Productivity and Competitiveness in Agriculture, Paris.

Paiva, R.M. (1971), "Modernização e dualismo tecnológico na agricultura", Pesquisa e Planejamento Econômico, vol. 1, No. 2, Institute of Applied Economic Research.

Pinto, A. (1970), "Natureza e implicações da heterogeneidade estrutural da América Latina", El Trimestre Económico, vol. 37, No. 1, Mexico City, Fondo de Cultura Económica. 
Pires, J.F. and J.F. Garcia (2004), "Productivity of nations: a stochastic frontier approach to TFP decomposition", Texto para Discussão, No. 143, São Paulo, Getulio Vargas Foundation.

Poudel, B.N., K.P. Paudel and D. Zilberman (2011), "Agricultural productivity convergence: myth or reality?", Journal of Agricultural and Applied Economics, vol. 43, No. 1.

Rodríguez, O. (1977), "On the conception of the centre-periphery system", CEPAL Review, No. 3, Santiago, Economic Commission for Latin America and the Caribbean (ECLAC).

Ruttan, V.W. (2002), "Productivity growth in world agriculture: sources and constraints", Journal of Economic Perspectives, vol. 16, No. 4, Nashville, Tennessee, American Economic Association.

Sadoulet, E. and A. de Janvry (1995), "Transactions costs and agrarian institutions", Quantitative Development Policy Analysis, Baltimore, The Johns Hopkins University Press.

Sunding, D. and D. Zilberman (2000), "The Agricultural Innovation Process: Research and Technology Adoption in a Changing Agricultural Sector" [online] http://are.berkeley.edu/ zilber11/ innovationchptr.pdf.

Sunkel, O. and R. Infante (orgs.) (2009), Hacia un desarrollo inclusivo: el caso de Chile (LC/L.3126), Santiago, Economic Commission for Latin America and the Caribbean (ECLAC).

Teixeira, E.C., F. Clemente and M.J.A. Braga (2013), "A contribuição das universidades para o desenvolvimento da agricultura no Brasil", Revista de Economia e Agronegócio, vol. 11, No. 1.

Thirtle, C. and P. Bottomley (1992), "Total factor productivity in UK agriculture, 1967-90", Journal of Agricultural Economics, vol. 43, No. 3, Wiley.

United States Department of Agriculture (2012), "Agricultural Productivity in the U.S.”, Economic Research Service [online] http://www.ers.usda.gov/Data/AgProductivity.

(2008), Total Factor Productivity, Washington, D.C., Economic Research Service.

Vicente, J.R. (2003), "Tecnologia, eficiência e produtividade total de fatores na agricultura brasileira, 1970-95", Brazilian Society of Rural Sociology and Economics (SOBER) [online] http://www. sober.org.br/palestra/2/633.pdf.
Vieira Filho, J.E.R. (2014), "Transformação histórica e padrões tecnológicos da agricultura brasileira", O mundo rural do Brasil no século 21: a formação de um novo padrão agrário e agrícola, A.M. Buainain and others (orgs.), Brasilia, Embrapa.

(2013), "The structural heterogeneity of family farming in Brazil", CEPAL Review, No. 111 (LC/G.2597-P), Santiago, Economic Commission for Latin America and the Caribbean (ECLAC).

(2012), "Technological trajectories and learning in agricultural sector", 10th globelics International Conference.

(2009), "Inovação tecnológica e aprendizado agrícola: uma abordagem schumpeteriana", thesis, Campinas, Institute of Economics/State University at Campinas.

Vieira Filho, J.E.R. and J.M.F. Silveira (2012), "Mudança tecnológica na agricultura: uma revisão crítica da literatura e o papel das economias de aprendizado", Revista de Economia e Sociologia Rural, vol. 50, No. 4, Brasilia, Brazilian Society of Rural Sociology and Economics.

(2011), "Modelo evolucionário de aprendizado agrícola", Revista Brasileira de Inovação, vol. 10, No. 4, Campinas.

Vieira Filho, J.E.R., A.C. Campos and C.M.C. Ferreira (2005), "Abordagem alternativa do crescimento agrícola: um modelo de dinâmica evolucionária", Revista Brasileira de Inovação, vol. 4, No. 2, Campinas.

Vieira Filho, J.E.R., G.R. Santos and A. Fornazier (2013), "Distribuição produtiva e tecnológica da agricultura brasileira e sua heterogeneidade estrutural", Texto para Discussão, No. 54 (LC/BRS/R.277), Brasilia, Economic Commission for Latin America and the Caribbean (ECLAC)/Institute of Applied Economic Research (IPEA).

Wilkinson, J. (2010), “Transformações e perspectivas dos agronegócios brasileiros", Revista Brasileira de Zootecnia, vol. 39, Brazilian Animal Production Society.

Yokoyama, L.P. and A.C.M. Igreja (1992), "Principais lavouras da região centro-oeste: variações no período 1975-1987”, Pesquisa Agropecuária Brasileira, vol. 27, No. 5. 